\title{
The Relationship between Parents' Child Rearing Styles and Their Children's Quality of Life and Mental Health
}

\author{
Mustafa Bolghan-Abadi ${ }^{*}$, Sayed Ali Kimiaee, Fatemeh Amir \\ Faculty of Educational Sciences \& Psychology, Ferdowsi University of Mashhad, Mashhad, Iran. \\ Email: mbolghan@gmail.com \\ Received November $9^{\text {th }}, 2010$; revised January $20^{\text {th }}, 2011$; accepted February $27^{\text {th }}, 2011$.
}

\begin{abstract}
Enhancing people's quality of life and their mental health is one of the challenges for the "World Health Organization". As parents have a close interpersonal relationship with their children, they play an important role in changing their children's quality of life and mental health. However, the important question is whether parents' child rearing styles affect children's quality of life and mental health. The purpose of this article is to investigate the role of parents' child rearing styles in children's quality of life and mental health. The main hypothesis is that the parenting styles have a significant role in predicting the quality of life and mental health. The population of the research included all of the high school students in Neyshabour city as well as their parents who were selected through a random sampling method. For data collection, Baumrind's parents' child rearing styles, the quality of life (WHOQOL-BREF) and Goldberg's mental health questionnaires were employed. For data analysis in the descriptive level mean, standard deviation and Pierson's correlation methods were utilized, and Multiple Regression Test was used at the inference level. The findings show that the main hypothesis is approved.
\end{abstract}

Keywords: Child Rearing Styles, Quality of Life, Mental Health

\section{Introduction}

The quality of life and mental health are two of the main factors of the general concepts of health (Park, 1995). According to international standards, health does not contain only the physical aspects. The "World Health Organization" has defined health as "the status in which one is mentally, emotionally, and socially in complete health with no symptoms of disease". Therefore, in evaluating the health conditions, not only should the traditional health indices, i.e. the mortality and affliction to disease rates be focused, but the people's perception of life quality should be considered as well (Campos, 2002). The definition of the "World Health Organization" for the quality of life is as follows: people's evaluation and perception of their own life status is under the influence of the cultural and value systems in which they are living, and in fact the aims, expectations, standards and a persons' needs that are extremely affected by his/her physical and mental status, the extent of independency, social relations and beliefs (WHO-QOL group, 1996; Mirkhani, 2001). Therefore, based on this comprehensive definition, the quality of life has a close relationship with the physical and mental statue, personal beliefs, self-sufficiency rates, social relationships and environment. Furthermore, Cella (1994), Cynthia (1998) and Evnase (1989) have defined the quality of life as one's satisfaction with all the aspects of life including mental, social, economic, cultural, spiritual and sexual ones.

Parents' child rearing styles are one of the world constructs (Darling, 1993), which express the emotional and general relationships between parents and children (Baumrind, 1991; Xie, 1996). The research supports the effect on and the role of parental control in creating antisocial behaviors, and Elise (quoted from Lanyado \& Horne, 1999) has pointed out that no problem is created if parental control in adolescents' viewpoints seems logical and is performed in a warm and friendly atmosphere, but if the control is done unemotionally, the antisocial behaviors of adolescents may increase. Most of adolescents and youths who have committed delinquencies are experiencing an insensible, cold, dismissive, and unbearable world. Research showed that most of the children with somatic complaints and somatization disorders are from inconstant families, and underwent misbehaviors (Blanchard, 2004; Craig et al., 1993; Lacner et al., 2007). The parents of these children are rough, disharmonious and inadaptable in their control using authoritarian child rearing styles (Radmanesh \& Shafei, 2003; Bloomquist, 2004). Parents' upbringing and child rearing styles are the important factors in changing and stabilizing the behavioral problems of children (Diaz, 2005; Conger et al., 1992). Baumrind defines the parenting style as the parental control function which is divided into three methods, namely authoritarian, authoritative and permissive (Mounts et al., 1994). The authoritarian child rearing style is identified with severe control, high restriction, rough and disharmonious discipline and a low level of emotional support. Evidence shows that the authoritarian style has a negative relationship with behavioral consequences including aggression, externalization, and lower emotional function. On the other hand, the authoritative child rearing style is identified with high levels of emotional support, proper independency, and a mutual relationship between parents and children. Based on the research conducted, this parenting style has a positive effect on educational advancement, more self-sufficiency, less misbehavior, and a better relationship with the peers (Laali-Faz \& Askari, 2008). Finally, a lack of parental control and good response to children's needs, which is called permissive child rearing style, leads to their 
delinquency and aggression for a lack of supervision and negligence on the part of parents (Bayrami, 2009). Based on the results of the research, the authoritative parenting style, especially connection and autonomy dimensions and socioeconomic status can decrease feelings of loneliness in female students (Dwairy \& Menshar, 2006). Yousefi (2007) has found a relationship between the child rearing styles of parents, the social skills and some self-concept aspects of high school students in Shiraz city. The results of the research conducted by Sohrabi \& Hasani (2007) showed that the authoritarian child rearing style, family collapse, substance abuse among family members, and educational failure have an effect upon the antisocial behavior of young girls, but parents' ages and the number of children have no effect on the above-mentioned behaviors. The results of Momeni and Amiri's research showed that there is a significant positive relationship between authoritarian style of parents and anorexia nervosa among female adolescents. Second, there is a significant negative relationship between the authoritative style of parents and anorexia nervosa among female adolescents. Third, no significant relationship between the permissive style of parents and anorexia nervosa was found in female adolescents. Therefore, they conclude that there is a relationship between child rearing styles and the incidence of anorexia nervosa and its subscales in female adolescents (Momeni \& Amiri, 2008). Nijhof \& Engels (2007) indicated that students brought up by authoritative and permissive parents experienced more and stronger feelings of homesickness than students brought up by authoritarian or uninvolved parents. Huver et al., (2010) found that there is a relationship between parental personality and parenting styles among 688 Dutch parents of adolescents.

Mental health is associated with authoritative parenting, but not with authoritarian parenting. It seems that authoritarian parenting within an dictatorial culture is not as harmful within a liberal culture (Dwairy \& Menshar, 2006). Parenting style is a significant factor in disease severity and the quality of life in children with cerebral palsy (Aran et al., 2007).

Based on the definition of the "World Health Organization", Since parents (especially mothers) have a close relationship with their children, the question remains to be answered whether there is any relationship between parent-child relations and children's quality of life and mental health. The aim of this research is to investigate the role of parents' child rearing styles in children's quality of life and mental health. The main hypothesis of this study indicates that the parents' child rearing styles have a significant role in predicting the quality of life and mental health of their children. The main hypothesis of the study indicates that there is a significant relationship between child rearing styles and children's quality of life and mental health. The sub-hypotheses are as follows:

a) Parenting styles have a significant role in senior high school students' mental health.

b) Parenting styles have a significant role in senior high school students' quality of life.

c) There is a significant correlation between parenting styles and the quality of life.

d) There is a significant correlation between parenting styles and mental health.

\section{Method}

In this case, the research method is descriptive and typical of correlation. For gathering data, a sample of 150 subjects is chosen in a random sampling method from all senior high school students and their parents from Neyshabour city.

\section{Participants}

For collecting data, 150 subjects of senior high school students ( 85 females and 65 males) were chosen in random sampling method for this research, 13 subjects of whom ( 7 females and 6 males) were dropped during the stage of filling out the questionnaires. The subjects included in the research reached 137 ones (78 females and 59 males), and consequently their parents' questionnaires were not included in the analysis. The age range of students was between 15 to 18 years old. (Mean = 16.21, Standard Deviation $=1.27$ ). The age range of mothers was also between 33 to 58 years old. (Mean $=38.2$, Standard Deviation 2.41).

\section{Procedure}

The students who were chosen as the research sample were collected through a calling up invitation, and then filled out the quality of life and mental health questionnaires. For conducting the child rearing styles of parents, the questionnaires were attached to a letter inside an envelope and sent to the mothers. Moreover, the aim of this research was explained to them through phone calls in order to induce further coordination.

\section{Measures}

Parents' child rearing styles questionnaire: this questionnaire was designed in 1972 by Dianna Baumrind. It consists of 30 Items in which every 10 Items test one style of parenting (authoritative style, permissive style, and authoritarian style). This questionnaire was normalized in Iran by Esfandyari (1984), whose reliability was reported by Cronbach's Alpha in authoritative, permissive, and authoritarian style, which were $0.73,0.69$, and 0.77 respectively. In this research, the test reliability is obtained via Cronbach's Alpha in which the permissive scale is 0.50 , the authoritative scale is 0.73 , and the authoritarian scale is 0.60 (Esfandyari, quoted from Rayisi, 2004).

Mental Health questionnaire: this questionnaire consists of 28 questions which were normalized by Tagavi (2001), whose reliability was obtained in three methods of retesting, splitting (split-half), and Cronbach's Alpha, which were 0.55, 0.72, and 0.87 , respectively. In this research, its reliability is also calculated at 0.96 via Cronbach's Alpha.

The Word Health Organization Quality of Life Questionnaire (WHOQOL-BREF): this questionnaire was purposely designed by the World Health Organization for evaluating the quality of life (Word Health Organization, 1998). In Iran, Nejat et al. normalized this scale, and the Alpha coefficient of the questionnaire was reported for healthy populations in the context of physical health, 0.70; mental health, 0.73; social relations, 0.55 , and environmental relations, 0.84 . The reliability coefficient of 
the retesting method was 0.7 after two weeks. In another research, the reliability of the questionnaire was obtained at 0.87 (Bolghan-Ababdi et al., 2010). In the current research, the reliability is estimated at 0.89 .

\section{Results}

For data analysis in the descriptive level mean, standard deviation and Pierson's correlation methods were used and Multiple Regression Test (Inter Method) was employed at the inference level.

In Table 1, the mean, Pierson correlation coefficient, and standard deviation are presented for mental health, quality of life, and parenting styles variables.

By considering the information in Table 1, there is a significant positive relation between the permissive style and the quality of life, and also between authoritative styles and mental health. That is, the more the marks of the permissive style, the better the marks of the students'quality of life of and vice versa, and the more the marks of the authoritative style, the better the marks of students' mental health and vice versa. Also, there is a significant negative relationship between the authoritarian style and the quality of life. That is, the more the marks of the authoritarian style, the worse the marks of quality of life and vice versa.

Table 2 shows that only the authoritative child rearing style could predict 0.22 of mental health variation $(p=0.009)$, but the other styles cannot significantly participate in evaluating mental health variation.

Table 3 also shows that the permissive child rearing style clarifies 0.44 of the quality of life variation, and there is also a positive relationship between them $(p=0.001)$; but the authoritarian child rearing style can only clarify 0.43 of the quality of life variation $(p<0.001)$, between which there is also a negative relationship. Research conclusions have approved the main hypothesis of the investigation.

Table 1.

Mean, standard deviation \& pierrson correlation coefficient.

\begin{tabular}{|c|c|c|c|c|c|c|}
\hline \multirow{2}{*}{ Indexes } & \multirow{2}{*}{$\begin{array}{c}\text { Mean } \\
\text { (Standard Deviation) }\end{array}$} & \multicolumn{5}{|c|}{ Pierson's Correlation Coefficient } \\
\hline & & Permissive & Authoritarian & Authoritative & Mental health & Quality of life \\
\hline Permissive & $\begin{array}{l}26.73 \\
(4.21)\end{array}$ & 1 & & & & \\
\hline Authoritarian & $\begin{array}{l}25.94 \\
(4.91)\end{array}$ & 0.047 & 1 & & & \\
\hline Authoritative & $\begin{array}{l}43.03 \\
(3.89)\end{array}$ & $0.274^{*}$ & -0.153 & 1 & & \\
\hline Mental health & $\begin{array}{c}68.54 \\
(22.51)\end{array}$ & 0.114 & -0.144 & $0.256^{*}$ & 1 & \\
\hline Quality of life & $\begin{array}{c}88.72 \\
(12.57)\end{array}$ & $0.409^{*}$ & $-0.404^{*}$ & 0.143 & -0.104 & 1 \\
\hline
\end{tabular}

*Correlation is significant at the 0.01 level (2-tailed).

Table 2 .

The results of linear regression (enter model) with mental health as criterion variable, and authoritative style, permissive style, and authoritarian style as predictors variables.

\begin{tabular}{|c|c|c|c|c|c|c|c|}
\hline \multicolumn{2}{|c|}{ Coefficients } & \multicolumn{2}{|c|}{ Unstandardized Coefficients } & \multirow{2}{*}{$\begin{array}{c}\text { Standardized Coefficients } \\
\text { Beta }\end{array}$} & \multirow{2}{*}{$\mathbf{t}$} & \multirow{2}{*}{ Sig. } & \multirow{2}{*}{$\begin{array}{c}\text { Collinearity Statistics } \\
\text { Tolerance }\end{array}$} \\
\hline & & B & Std. Error & & & & \\
\hline \multirow{4}{*}{ styles } & (Constant) & 18.345 & 24.031 & & 0.763 & 0.446 & \\
\hline & authoritative & 1.287 & 0.485 & 0.222 & 2.654 & $0.009^{*}$ & 0.897 \\
\hline & permissive & 0.310 & 0.443 & 0.058 & 0.699 & 0.485 & 0.916 \\
\hline & authoritarian & -0.519 & 0.370 & -0.113 & -1.403 & 0.163 & 0.968 \\
\hline
\end{tabular}

* is significant at the 0.01 level. $(\mathrm{F}(\mathrm{df}=3,146)=4.220, \mathrm{p}=0.007$, Adjusted $\mathrm{R} 2=0.061)$

Table 3 .

The results of linear regression (enter model) with the quality of life as criterion variable, and authoritative style, permissive style, and authoritarian style as predictors variables.

\begin{tabular}{|c|c|c|c|c|c|c|c|}
\hline & \multirow{2}{*}{ Coefficients } & \multicolumn{2}{|c|}{ Unstandardized Coefficients } & \multirow{2}{*}{$\begin{array}{c}\text { Standardized Coefficients } \\
\text { Beta }\end{array}$} & \multirow{2}{*}{$\mathbf{t}$} & \multirow{2}{*}{$p$} & \multirow{2}{*}{$\begin{array}{c}\text { Colinearity Statistics } \\
\text { Tolerance } \\
\end{array}$} \\
\hline & & B & Std. Error & & & & \\
\hline \multirow[t]{3}{*}{ styles } & (Constant) & 88.415 & 11.283 & & 7.836 & 0.000 & \\
\hline & permissive & 1.317 & 0.208 & 0.442 & 6.337 & $0.000^{*}$ & 0.916 \\
\hline & authoritarian & -1.106 & 0.174 & -0.432 & -6.368 & $0.000^{*}$ & 0.968 \\
\hline
\end{tabular}




\begin{tabular}{rrrrrr}
\hline authoritative & -0.144 & 0.228 & -0.045 & -0.634 & 0.527 \\
\hline
\end{tabular}

* are significant at the 0.01 level. $(\mathrm{F}(\mathrm{df}=3,146)=26.110, \mathrm{p}=<0.001$, Adjusted $\mathrm{R} 2=0.336)$

\section{Discussion}

The present research was conducted by the aim of considering the role of parents' child rearing styles in the quality of life and mental health of children. The research conclusion showed that the more authoritative parents the senior high school students of Neyshabour city have, the more mental health they enjoy. These research findings are in mutual accord with the previous Iranian research findings (e.g. Pourahmadi et al., 2009; Momeni \& Amiri, 2008; SeyedMosavi et al., 2008; Hoseini Nasab et al., 2008; Zahrakar, 2008) and simlar foreign researches (e.g. Dwairy \& Menshar, 2006; Buri et al., 1988; Lamborn et al., 1991; Wenar, 1994). Another finding derived from this research is the students who have permissive parents enjoy a higher rate of quality of life. On the other hand, the students who have authoritarian parents enjoy a lower rate of quality of life. This finding is in mutual accord with previous researches (e.g. Yousefi, 2008; Sohrabi \& Hasani, 2007; Laali-Faz \& Askari, 2008; Bayrami, 2009). The limitations related to previous researches is that instead of using the child rearing styles of parents, a perceived form was usually employed for children, in which it was possible that the children had not yet reached a proper understanding of their parents' child rearing styles. One potential problem of the study is the lack of face-to-face relationship with the participants' mothers, such that the mothers' responses could be biased; however, we tried to minimize the problem via providing them with extensive written information prior to the completion of the measures.

\section{Acknowledgements}

We warmly thank all the teachers, and colleagues whom we have consulted so frequently, and the students who has helped so much at every stage in this study.

\section{References}

Aran, A., Shalev, R. S., Biran, G., \& Gross-Tsur, V. (2007). Parenting style impacts on quality of life in children with cerebral palsy. The Journal of Pediatrics, 1, 56-60. doi:10.1016/j.jpeds.2007.02.011

Baumrind, D. (1991). Parenting styles and adolescent development. In J. Brooks-Gunn, R. M. Lerner, \& A. C. Petersen (Eds.), The encyclopedia on adolescence (pp. 746-758). New York: Garland Publishing.

Bayrami, M. (2009). The effect of instruction of parenting skills to mothers of boys with externalizing symptoms on mental health and their parenting styles. The Quarterly Journal of Fundamentals of Mental Health, 2, 105-114.

Beck, J. E. (2007). A developmental perspective on functional somatic symptoms. Journal of Pediatric Psychology, 86, 1083-1094.

Bloomquist, M. L. (2004). Coping skills with maladaptive child. Tehran: Sana Publication.

Bolghan-Abadi, M., Soltani, R., \& Abde Khodayi, M. S. (2010, October). The effect of collective pray on quality of life and meaningful in students. Paper presented at the $1^{\text {st }}$ Student National Congress on: Social Determinants of Health, Tehran: Medical Sciences University of Iran.

Buri, J. R., Louiselle, P. A., Misukanis, T. M., \& Mueller, R. A. (1988). Effects of parental authoritarianism and authoritativeness on self-esteem. Personality and Social Psychology Bulletin, 14, 271-282. doi:10.1177/0146167288142006

Campos, M. G. (2002). Quality of life differences between first year undergraduate financial aid and non-aid recipients. Unpublished Master Thesis.

Cella, D. F. (1994). Quality of life: Concepts and definition. Journal of Pain Symptom Management, 9, 186-192. doi:10.1016/0885-3924(94)90129-5

Conger, R. D., Conger, K. J., Elder, G. H., Lorenz, F. O., Simons, R. L., \& Whitbeck, L. B. (1992). A family process model of economic hardship and adjustment of early adolescent boys. Child Development, 6, 526-541. doi: $10.2307 / 1131344$

Craig, T. K., Boardman, A. P., \& Mills K. (1993). The South London somatization study. I: Longitudinal course and the influence of early life experiences. The British Journal of Psychiatry, 163, 579-588. doi:10.1192/bjp.163.5.579

Cynthia, R. K. (1998). Overview of quality of life controversial issues, In: Cynthia R. K., \& Hinds, P. S. (Eds.), Quality of life from nursing and patient perspectives (pp. 23-30). Canada: Jones and Bartlett.

Darling, N., \& Steinberg, L. (1993). Parenting style as context: An integrative model. Psychological Bulletin, 1113, 487-496. doi:10.1037/0033-2909.113.3.487

Diaz, Y. (2005). Association between parenting and child behavior problems among mothers and children, Dissertation, University of Maryland.

Dwairy, M., \& Menshar, K. E (2006). Parenting style, individuation, and mental health of Egyptian adolescents. Journal of Adolescence, 1, 103-117. doi:10.1016/j.adolescence.2005.03.002

Evanse, D. R., \& Cope, W. E. (1989). Manual of the QOL questionnaire. North Ton wad: Multi Health System Inc.

Hoseini Nasab, A., Ahmadian, F., \& Ravanbakhsh, M. H. (2008). The study of ralationship between parenting styles with self-efficacy and mental health in students. Educational \& Psychological Studies, 9, 21-37.

Huver, R. M. E., Otten, R., De Vries, H., \& Engles, R. C. M. E. (2010). Personality and parenting style in parents of adolescents. Journal of Adolescence, 3, 395-402. doi:10.1016/j.adolescence.2009.07.012

Laali-Faz, A., \& Askari, A. A. (2008). The power of predicting perceived parenting styles and demographic variables on girl student's loneliness feeling. The Quarterly Journal of Fundamentals of Mental Health, 37, 71-78.

Lackner, J. M., Gudleski, G. D., \& Blanchard, E. B. (2004) Beyond abuse: the association among parenting style, abdominal pain, and somatization in IBS patients. Behavior Research Therapy, 42, 41-56. doi:10.1016/S0005-7967(03)00069-X

Lamborn, S. D., Mants, N. S., Steinberg, L., \& Dornbusch, S. M. (1991). Patterns of competence and adjustment among adolescents from authoritative, authoritarian, indulgent, and neglectful families. Child Development, 62, 1049-1106. doi:10.2307/1131151

Lanyado, M,. \& Horne, A. (1999). Adolescent affect and health. Europe: The European Association for Research an Adolescent.

Mirkhani, M. (2001). Fundamental of rehabilitation. Tehran: Welfare organization.

Momeni, F., \& Amiri, Sh. (2008). The Relationship between parents' child rearing styles and incidence of anorexia nervosa among 14-17 years old female adolescents in Isfahan. Family Research, 3, 775-789.

Nejat, S., Montazeri, A., Halakuyi Nayini, K., Kazem, M., \& Majd Zadeh, S. R. (2006). Validation and normalization world health organization quality of life questionnaire. Scientific Journal of School of Public Health and Institute of Public Health Research, 4, 1-12.

Nijhof, K. S., \& Engels, R. C. M. E. (2007). Parenting styles, coping strategies, and the expression of homesickness. Journal of Adolescence, 5, 709-720. doi:10.1016/j.adolescence.2006.11.009 
Park, K. (1995). Parks' text book of preventive and social medicine (14th ed.). Jabalpur: Banarsidas Bhanot Publishers.

Pourahmadi, E., Jalali, M., Roshan, R., \& Abedin, A. (2008). The effect of the triple p-positive parenting program on children with somatic complaints. Journal of Babol University of Medical Sciences, 11, 72-77.

Radmanesh, M., \& Shafei, S. (2003). Psychopathology of skin psychosomatic disorders. Skin Pharmacology, 3, 135-43.

Rayisi, A. (2004). The study of relationship between parenting styles with mental health of high school female students in Esfahan. Post graduate dissertation, Unpublished. Isfahan: University of Esfahan.

SeyedMosavi, S. P., Nad Ali, H., \& Ghanbari, S. (2008). The study of relationship between parenting styles and externalizing symptoms in 7 to 9 year old children, Journal of Family Research, 4, 37-49.

Sohrabi, F. \& Hasani, A. (2007). Parenting styles and anti-social behaviuors of female adolescents. Journal of Psychology, 11, 74-88.

Steinberg, L., Lamborn, S. D., Darling, N., Mounts, N. S., \& Dornbusch, S. M. (1994). Over-time changes in adjustment and competence among adolescents from authoritative, authoritarian, indulgent, and neglectful families. Child Development, 6, 754-770. doi: $10.2307 / 1131416$

Tagavi, M. R. (2001). Validity and reliability of general health questionnaire. Journal of psychology of Tehran University, 5, 35-44

Wenar, C. (1994). Developmental Psychopathology: From infancy through adolescence. New York: McGraw-Hill.

WHO-QOL group. (1996). What is quality of life?. World health organization, 17, 354-356.

Xie, Q. (1996). Parenting style and only children's school achievement in China. Paper presented at the Annual Conference of the American Educational Research Association, New York, ERIC Document Reproduction Service No. ED396819.

Yousefi, F. (2007). The Relationship between parenting styles, social skills and aspects of self-concepts in high school students. Bimonthly Paper of Behavior Scholar of Shahed University, 14, 37-46.

Zahrakar, K. (2008). The study of the relationship between parenting styles with mental health of islamshahrs' adolescents. The Quarterly of New Thoughts in Educational Sciences, 3, 77-91. 